\title{
Walleye growth declines following zebra mussel and Bythotrephes invasion
}

\author{
Gretchen J. A. Hansen (iD) Tyler D. Ahrenstorff • Bethany J. Bethke • \\ Joshua D. Dumke · Jodie Hirsch • Katya E. Kovalenko • Jaime F. LeDuc • \\ Ryan P. Maki $\cdot$ Heidi M. Rantala $\cdot$ Tyler Wagner
}

Received: 3 July 2019/Accepted: 3 January 2020/Published online: 24 January 2020

(C) The Author(s) 2020

\begin{abstract}
Invasive species represent a threat to aquatic ecosystems globally; however, impacts can be heterogenous across systems. Documented impacts of invasive zebra mussels (Dreissena polymorpha) and spiny water fleas (Bythotrephes cederströmii; hereafter Bythotrephes) on native fishes are variable and context dependent across locations and time periods. Here, we use a hierarchical Bayesian analysis of a 35-year dataset on two fish species from 9 lakes to demonstrate that early life growth of ecologically
\end{abstract}

Electronic supplementary material The online version of this article (https://doi.org/10.1007/s10530-020-02198-5) contains supplementary material, which is available to authorized users.

G. J. A. Hansen ( $₫)$

Department of Fish, Wildlife, and Conservation Biology, University of Minnesota, St. Paul, MN 55188, USA

e-mail: ghansen@umn.edu

T. D. Ahrenstorff

Minnesota Department of Natural Resources, 1601

Minnesota Dr, Brainerd, MN 56425, USA

\section{B. J. Bethke $\cdot$ H. M. Rantala}

Minnesota Department of Natural Resources, 5351 North

Shore Dr, Duluth, MN 55804, USA

Joshua D.Dumke · K. E. Kovalenko

Natural Resources Research Institute, University of Minnesota Duluth, 5013 Miller Trunk Hwy, Duluth, MN 55811, USA important fishes are influenced by these aquatic invasive species. Walleye (Sander vitreus) in their first year of life grew more slowly in the presence of either invader after correcting for temperature (measured by degree days), and were on average 12 or $14 \%$ smaller at the end of their first summer following invasion by Bythotrephes or zebra mussels, respectively. Yellow perch (Perca flavescens) growth was less affected by invasion. Yellow perch on average grew more slowly in their first year of life following invasion by zebra mussels, although this effect was not statistically distinguishable from zero. Early life growth of both walleye and yellow perch was less tightly coupled to degree days in invaded systems, as

\author{
J. Hirsch \\ Minnesota Department of Natural Resources, 500 \\ Lafayette Rd, St Paul, MN 55155, USA \\ J. F. LeDuc · R. P. Maki \\ Voyageurs National Park, 360 Highway 11 East, \\ International Falls, MN 56649, USA \\ T. Wagner \\ U.S. Geological Survey, Pennsylvania Cooperative Fish \\ and Wildlife Research Unit, Pennsylvania State \\ University, 402 Forest Resources Building, \\ University Park, PA 16802, USA
}


demonstrated by increased variance surrounding the degree day-length relationship. Smaller first-year size is related to walleye survival and recruitment to later life stages and has important implications for lake food webs and fisheries management. Future research quantifying effects of zebra mussels and Bythotrephes on other population-level processes and across a wider gradient of lake types is needed to understand the mechanisms driving observed changes in walleye growth.

Keywords Walleye - Yellow perch - Zebra mussel · Spiny water flea $\cdot$ Indirect effects $\cdot$ Food web . Growth · Lake · Impacts · Historical data · Fisheries

\section{Introduction}

Zebra mussels (Dreissena polymorpha) and spiny water fleas (Bythotrephes cederströmii; Korovchinsky and Arnott 2019; hereafter Bythotrephes) are aquatic invasive species (AIS) that transform freshwater ecosystems. Zebra mussels are filter feeders that reduce pelagic primary production and increase water clarity (Macisaac 1996; Strayer et al. 1999; Karatayev et al. 2002). They also indirectly affect zooplankton biomass, size structure, and community composition (Pace et al. 1998; Idrisi et al. 2001; Higgins and Vander Zanden 2010). At the same time, zebra mussels can increase benthic primary production and biomass of some benthic invertebrates by shunting nutrients into benthic zones and providing additional structure (Vanderploeg et al. 2001; Hecky et al. 2004; Higgins and Vander Zanden 2010). Bythotrephes are predatory zooplankters that also reduce native zooplankton biomass and can shift zooplankton community composition to prey species that are suboptimal for fish via both direct predation and indirect effects (Yan and Pawson 1997; Hoffman et al. 2001; Barbiero and Tuchman 2004; Fernandez et al. 2009; Rennie et al. 2011; Kerfoot et al. 2016). These changes in the zooplankton community can decrease water clarity via a trophic cascade (Walsh et al. 2016), although effects on phytoplankton communities vary among lakes (Strecker et al. 2006, 2011).

Despite their documented effects on lower trophic levels and ecosystem functioning, the effects of zebra mussels and Bythotrephes on higher trophic levels such as fish are less well known and appear to vary among systems and species (Strayer et al. 2004; Higgins and Vander Zanden 2010). Fish species and life stages that rely on pelagic energy sources are often negatively affected by zebra mussels, while those that rely on benthic/littoral resources often respond positively in terms of growth and abundance (e.g., Strayer et al. 2004; Guiliano 2011; Kaemingk et al. 2012; but see McNickle et al. 2006; Lumb et al. 2007; Nalepa et al. 2009). The eponymous spine of the Bythotrephes can make them difficult to ingest for many planktivorous fishes. Fish above a certain size may consume Bythotrephes, although the spines can cause internal damage and can lead to learned avoidance (Barnhisel and Kerfoot 2004; Compton and Kerfoot 2004).

Walleye (Sander vitreus) and yellow perch (Perca flavescens) are economically and ecologically important fish species in North America, and the ecosystem changes associated with zebra mussel and Bythotrephes invasions may affect first year growth and survival of these fishes. Both walleye and yellow perch rely on zooplankton prey for a portion of their first year of life before switching to benthic macroinvertebrates and then fish (Wu and Culver 1992; Mittelbach and Persson 1998; Galarowicz et al. 2006). If native zooplankton become limited due to the presence of either AIS, walleye and yellow perch may switch to alternative food sources if they are large enough to make that shift (Wu and Culver 1992; Gopalan et al. 1998) or continue to persist on pelagic resources (Bremigan et al. 2003; Truemper et al. 2006). In either case, their growth may be affected. Growth of these fishes during the first year is critical to survival to later life stages, because larger individuals are less likely to succumb to size-selective predation (Nielsen 1980; Roswell 2011) and have access to a more diverse prey base (Wu and Culver 1992).

The impacts of zebra mussels and/or Bythotrephes on first year walleye or yellow perch growth are inconsistent in both direction and magnitude across studies to date. Zooplankton declines were associated with decreased age- 0 yellow perch growth in lakes containing Bythotrephes (Staples et al. 2017). Zebra mussels caused reduced larval perch growth in mesocosms (Mavrin and Strel'nikova 2011), whereas in natural systems (e.g. Lake Oneida, New York) there are conflicting reports of either increased (Mayer et al. 2000) or unchanged (Idrisi et al. 2001) growth following zebra mussel establishment. Walleye 
biomass dropped by approximately half post-zebra mussel invasion in Lake Oneida (Irwin et al. 2008), while no effect of zebra mussels on age-0 growth of any species including yellow perch and walleye was observed in Lake Erie (Trometer and Busch 1999). Length-specific differences in growth and condition of yellow perch and walleye in zebra mussel infested lakes have also been documented, with larger individuals growing faster, suggesting impacts of zebra mussels on fishes may vary with fish life stage (Mavrin and Strel'nikova 2011; Nienhuis et al. 2014).

The context-dependent impacts of zebra mussels and Bythotrephes on fish growth are common in studies of invasive species impacts (Parker et al. 1999). If the effects of zebra mussels and Bythotrephes on fish really differ among systems, identifying characteristics associated with resilient versus vulnerable populations will be critical for prioritizing invasive species prevention efforts, managing fisheries, and predicting the effects of invasion in uninvaded lakes. Generalizability can be achieved by moving beyond single system case studies to examining impacts across multiple locations and over longer, management-relevant time frames. Here, we evaluated changes in first year growth of walleye and yellow perch pre- and post-invasion in lakes invaded by zebra mussels and/or Bythotrephes. We examined data from 9 lakes sampled over 35 years to estimate AIS impacts at management-relevant spatial and temporal scales. To correct for temperature effects on fish growth, we standardized growth by degree days (cumulative daily temperatures $>5^{\circ} \mathrm{C}$ ) and tested for differences in the temperature-standardized rates of growth. We hypothesized that young of year growth of both yellow perch and walleye would be slower in invaded systems due to decreased availability of suitably sized zooplankton resources.

\section{Methods}

\section{Study lakes}

We examined walleye and yellow perch growth rates in nine lakes in Minnesota, USA (Fig. 1), ranging in area from 6500 to 309,000 ha and maximum depths from 5 to $64 \mathrm{~m}$ (Table 1). These lakes are important economic, cultural, and ecological resources in the state (MN DNR 1997), accounting for $33 \%$ of

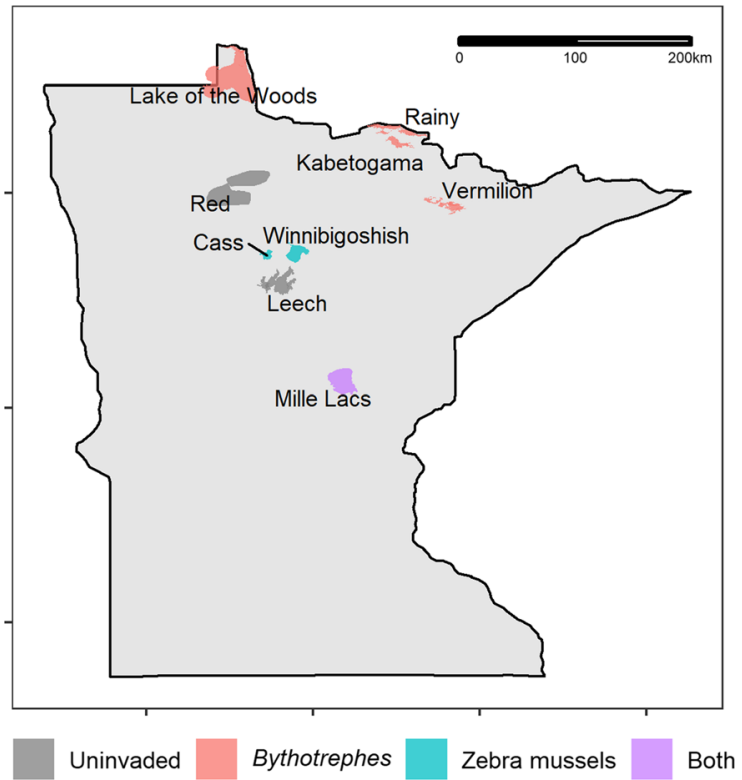

Fig. 1 Study lake locations colored by the invasion status during this study

Minnesota's walleye harvest (Jacobson 2004) and contributing significantly to the $\$ 2.4$ billion spent each year on fishing in Minnesota (U.S. Department of the Interior et al. 2011). Our study lakes vary in invasion status and timing (Table 1); zebra mussels are present in two lakes, Bythotrephes are present in four lakes, both species are present in one lake, and two lakes were uninvaded at the time of study. For this study, we consider timing of invasion as the year zebra mussel adults were discovered or two years after the discovery of Bythotrephes, which corresponds to the lag documented between discovery of Bythotrephes and impacts on the zooplankton community (Staples et al. 2017). Zebra mussel veligers were found in Leech Lake in 2016 and Red Lake in 2018, but no adults were confirmed as of 2018 and thus we considered these lakes uninvaded for the time period of this study. Lake Vermilion has two discrete basins (East and West), which are connected by a relatively small channel $(1 \mathrm{~km}$ long and $\sim 100 \mathrm{~m}$ wide at its narrowest location). Bythotrephes were discovered in East Vermilion in 2015 and were not documented in West Vermilion until 2018, therefore, we split Lake Vermilion into East and West basins for analysis and considered West Vermilion uninvaded for this study. Significant declines in total zooplankton biomass have been documented in each of the study lakes invaded by 
Table 1 Characteristics of study lakes, invasion year by zebra mussels (ZM) and Bythotrephes (Bytho.), and age-0 walleye (WAE) and yellow perch (YEP) samples used in this analysis

\begin{tabular}{|c|c|c|c|c|c|c|c|c|}
\hline Lake & $\begin{array}{l}\text { Area } \\
\text { (ha) }\end{array}$ & $\begin{array}{l}\text { Max } \\
\text { depth } \\
\text { (m) }\end{array}$ & $\begin{array}{l}\text { Median } \\
\text { Secchi depth } \\
\text { (m) }\end{array}$ & $\begin{array}{l}\text { Invasion year } \\
\text { (species) }\end{array}$ & $\begin{array}{l}\text { \# YEP } \\
\text { sampled }\end{array}$ & $\begin{array}{l}\text { \# WAE } \\
\text { sampled }\end{array}$ & $\begin{array}{l}\text { \# years } \\
\text { sampled }\end{array}$ & $\begin{array}{l}\text { August } 15 \text { median } \\
\text { degree day value (range) }\end{array}$ \\
\hline Cass & 6458 & 37 & 3.4 & $2014(\mathrm{ZM})$ & 11,246 & 1371 & 29 & $1424(1185-1789)$ \\
\hline Kabetogama & 9727 & 24 & 2.4 & 2007 (Bytho.) & 39,036 & 13,687 & 34 & $1358(1086-1640)$ \\
\hline $\begin{array}{l}\text { Lake of the } \\
\text { Woods }^{\mathrm{a}}\end{array}$ & 309,276 & 64 & 1.1 & 2007 (Bytho.) & 17,129 & 4752 & 27 & $1257(950-1513)$ \\
\hline Leech & 44,641 & 46 & 2.7 & & 14,104 & 5209 & 31 & $1478(1248-1820)$ \\
\hline Mille Lacs & 51,891 & 13 & 3.1 & $\begin{array}{l}2005 \text { (ZM), } \\
2009 \\
\text { (Bytho.) }\end{array}$ & 9579 & 1555 & 14 & $1514(1276-1913)$ \\
\hline Rainy $^{a}$ & 85,065 & 49 & 2.4 & 2006 (Bytho.) & 38,290 & 6189 & 30 & 1373 (1059-1667) \\
\hline Upper Red & 48,297 & 5 & 0.8 & & 12,530 & 8711 & 35 & $1459(1163-1758)$ \\
\hline $\begin{array}{l}\text { Vermilion } \\
\text { (East) }\end{array}$ & 11,400 & 23 & 2.4 & 2015 (Bytho.) & 12,787 & 2488 & 34 & $1254(1010-1553)$ \\
\hline $\begin{array}{l}\text { Vermilion } \\
\text { (West) }\end{array}$ & 4599 & 15 & 3.1 & & 13,945 & 555 & 34 & $1254(1010-1553)$ \\
\hline Winnibigoshish & 22,853 & 21 & 3.1 & 2014 (ZM) & 8337 & 5495 & 34 & $1450(1219-1763)$ \\
\hline
\end{tabular}

${ }^{a}$ Lake of the Woods and Rainy Lake are border lakes, only a portion of which are in Minnesota, USA

August 15 degree day value is based on air temperatures and calculated using a base of $5{ }^{\circ} \mathrm{C}$

Bythotrephes. Cladocerans and cyclopoid copepods were impacted the most, with the zooplankton shifting to a community dominated by calanoid copepods (Kerfoot et al. 2016; Hirsch, unpublished data). Decreasing trends in total zooplankton biomass have also been detected in each of the study lakes invaded by zebra mussels, with parallel declines among all zooplankton taxa in these communities (Hirsch, unpublished data).

\section{Data collection and collation}

Age-0 walleye and yellow perch were collected from 1983 to 2018 by shoreline seining as part of the Minnesota Department of Natural Resources standardized large lakes monitoring program (Wingate and Schupp 1984). A 30-m long, 2-m deep, 6.4-mm bar mesh bag seine was used with a fixed pole seining technique, where one braille is fixed on shore while the other begins perpendicular to shore and is pulled toward shore in a sweeping motion while keeping the net taut. Seining began in 1983 for several lakes and was conducted annually with some exceptions (Table 1). An average of 13 stations (range 6-23 stations) were sampled in each lake during each sampling year. The same stations within each lake were typically sampled weekly, from mid-July to midAugust. All fishes were identified and enumerated. Walleye and yellow perch total length (TL) was measured to the nearest $\mathrm{mm}$. To verify that only age- 0 individuals were used in subsequent analyses, the data were quality checked by plotting length-frequency histograms for each species by lake, year, and week (nested within year). Data considered out of range of age- 0 cohorts (either erroneous data or suspected age$1+$ individuals) were removed. The remaining age- 0 walleye and yellow perch individual lengths were corrected for growing degree days, as described below, allowing for standardized comparisons.

To account for differences in age- 0 fish length due to differences in temperature, we calculated cumulative degree days with a $5{ }^{\circ} \mathrm{C}$ base (Chezik et al. 2013) for each sample date in each lake. Because we lacked water temperature data for the time period of analysis, we used air temperature as a proxy for surface water temperature when calculating degree days (Honsey et al. 2019). We acquired daily air temperature data for degree day calculation from NCEP North American 
Regional Reanalysis (NARR) provided by the NOAA/ OAR/ESRL PSD, Boulder, Colorado, USA, from their Web site at https://www.esrl.noaa.gov/psd/. Grid resolution for NARR data is approximately $0.3^{\circ}(32 \mathrm{~km})$ at the lowest latitude. Lake-specific daily air temperatures were extracted using the geoknife package (Read et al. 2015) in $\mathrm{R}$ version 3.5.1 ( $\mathrm{R}$ Core Team 2018) with lake centroids as inputs. Degree day values were centered by subtracting the mean degree day value for each species to improve model convergence.

\section{Statistical analysis}

We used Bayesian hierarchical linear models to evaluate the effects of invasion on first year growth of walleye and yellow perch. We fit separate models for walleye and yellow perch. For each species, the model was as follows:

$$
\begin{aligned}
& y_{i} \sim N\left(\alpha_{j(i)}+\beta_{j(i)} \cdot D D_{i}+\eta_{k(i)}, \sigma_{j}^{2}\right), \\
& \quad \text { for } i=1 \ldots n \text { observations } \\
& \eta_{k} \sim N\left(0, \sigma_{\eta}^{2}\right) \text { for } k=1 \ldots K \text { lakes } \\
& \left(\begin{array}{c}
\alpha_{j} \\
\beta_{j}
\end{array}\right) \sim M V N\left(\left(\begin{array}{c}
\gamma_{0}^{\alpha}+\gamma_{1}^{\alpha} \cdot Z_{1 j}+\gamma_{2}^{\alpha} \cdot Z_{2 j} \\
\gamma_{0}^{\beta}+\gamma_{1}^{\beta} \cdot Z_{1 j}+\gamma_{2}^{\beta} \cdot Z_{2 j}
\end{array}\right), \Sigma\right), \\
& \quad \text { for } j=1 \ldots J \text { lake-years } \\
& \log \left(\sigma_{j}\right) \sim N\left(\gamma_{0}^{\sigma}+\gamma_{1}^{\sigma} \cdot Z_{1 j}+\gamma_{2}^{\sigma} \cdot Z_{2 j}, \omega^{2}\right), \\
& \quad \text { for } j=1 \ldots J \text { lake-years }
\end{aligned}
$$

where $y_{i}$ is an individual fish length $(\mathrm{mm})$ for observation $i$ (for a given lake-year), $\alpha_{j}$ and $\beta_{j}$ are the intercepts and slopes that describe the relationship between first year length and degree days $\left(D D_{i}\right)$ on the day of sample for lake-year $j$, and $\sigma_{j}^{2}$ is the residual variance, which was also allowed to vary by lake-year $j$. Specifically, the residual standard deviations, $\sigma_{j}$, are assumed to follow a log-normal distribution with a linear predictor equal to $\gamma_{0}^{\sigma}+\gamma_{1}^{\sigma} \cdot Z_{1 j}+\gamma_{2}^{\sigma} \cdot Z_{2 j}$ and a conditional variance $\omega^{2}$. Degree days were standardized by subtracting the mean and dividing by the standard deviation prior to analysis. We assumed a linear relationship between fish length and degree days accumulated to that date (Neuheimer and Taggart 2007; Staples et al. 2017). The lake-year specific intercepts, slopes, and residual standard deviations were modeled as a function of invasion status of each lake-year, where $Z_{1}=1$ if a lake-year was invaded by the Bythotrephes, $\mathrm{Z}_{2}=1$ if a lake-year was invaded by zebra mussels. If $Z_{1}$ and $Z_{2}$ both equaled 1 , then a lakeyear was invaded by both Bythotrephes and zebra mussels and if $\mathrm{Z}_{1}$ and $\mathrm{Z}_{2}$ both equaled zero then a lakeyear was not invaded. The parameters $\gamma_{n}^{x}$ describe the effects of invasion status on the lake-year specific intercepts, slopes, and residual standard deviations. The parameter $\eta_{k}$ is a lake random effect, assumed to be normally distributed with a mean of zero and variance $\sigma_{\eta}^{2}$. We modeled the variance-covariance matrix $(\Sigma)$ of the multivariate normal distribution for the varying slopes and intercepts using the scaled inverse-Wishart distribution (Gelman and Hill 2007). Diffuse normal priors were used for $\gamma_{n}^{x}$, and diffuse uniform priors were used for $\sigma_{\eta}$ and $\omega$. We ran three parallel Markov chains beginning each chain with random starting values. Each chain was run for 60,000 iterations, from which the first 30,000 were discarded. Each chain was thinned to 10,000 samples, resulting in a total of 30,000 samples used to summarize the posterior distributions. Convergence was assessed visually through inspection of trace plots and quantitatively using the Brooks-Gelman-Rubin statistic (Brooks and Gelman 1997). Models were fit by calling the program JAGS (Plummer 2003) using the jagsUI package (Kellner 2018) in R (R Core Team 2018). Data and $\mathrm{R}$ code are available at the University of Minnesota's digital conservancy data repository (https://hdl.handle.net/11299/208865).

We used this model to test whether the parameters relating degree days to fish length $\left(\gamma_{n}^{x}\right)$ differed as a function of invasion status. We assessed significance of group differences by calculating differences between parameters in each of 10,000 samples from the posterior distributions. We then evaluated whether the $90 \%$ credible interval of differences between coefficients contained zero. Additionally, we predicted fish lengths across a range of degree day values to compare predicted lengths among individual lakeyears as well as for invaded and uninvaded lakes in general, while accounting for uncertainty in all parameters. Walleye and yellow perch lengths were predicted for the observed range of degree day values as a function of invasion status using 10,000 samples from the posterior distributions of parameter estimates. We also calculated the posterior probability that walleye and yellow perch in invaded systems were smaller than those in uninvaded systems as a function 
of degree days. Because end-of-season length is particularly important for overwinter survival, we also predicted lengths for each invasion status at 1400 degree days, the median degree day value across all lake years for August 15. Finally, we predicted lakeand year-specific length on August 15 based on the median degree day value for that date in each lake to account for differences in temperature among lakes and years and their influence on end of summer length. For each of these analyses, we predicted fish length across 10,000 samples from the posterior distribution; summary statistics such as mean, probabilities, and credible intervals are summarized from this distribution of estimates. We calculated differences in predicted length between invasion status, lakes, and lake-years based on differences in predicted lengths across the 10,000 samples, and assess significance based on whether the $90 \%$ credible intervals of the differences in predicted lengths contained zero.

\section{Results}

We collated 50,012 walleye and 176,983 yellow perch individual fish lengths collected between mid-June and early September from 1983 to 2018. Walleye ranged from 15 to $162 \mathrm{~mm}$ at the time of capture $($ median $=64 \mathrm{~mm})$. Yellow perch ranged from 10 to $80 \mathrm{~mm}$ at the time of capture $($ median $=38 \mathrm{~mm}$ ). Cumulative degree days varied among lakes and years (Figure S1). Lake Vermilion was on average the coldest lake (range [median] end of year degree days 1423-2172 [1816]), while Mille Lacs was on average the warmest lake (1791-2571 [2178]).

\section{Walleye}

Age-0 walleye were smaller at mid-summer when zebra mussels were present (Fig. 2; intercept). Walleye lengths at mid-summer-were $6.5 \mathrm{~mm}(9.2 \%)$ smaller on average than in uninvaded systems (Table 2). On average, age-0 walleye grew more slowly per degree day increase when zebra mussels were present (Fig. 2; slope). On average walleye grew $4.02 \mathrm{~mm}$ less per standardized degree day or $19 \%$ slower growth when zebra mussels were present, although the $90 \%$ credible interval of this difference included zero (Table 2). Additionally, walleye exhibited higher variability in growth per degree day when zebra mussels were present (Fig. 2; SD) with a, mean difference of 0.15 (6.6\% more variable; Table 2$)$.

Age-0 walleye growth was also reduced in systems invaded by Bythotrephes (Fig. 2). The presence of Bythotrephes was associated with a $9 \mathrm{~mm}(12.8 \%)$ reduction in mid-summer length (intercept) and a reduced growth rate of $1.99 \mathrm{~mm}$ per standardized degree day or $9.6 \%$ slower growth (slope; Table 2). In contrast to zebra mussels, Bythotrephes presence was not associated with any difference in the variability of walleye growth per degree day (Table 2; SD, median difference is -0.05 or $2 \%$ less variable, $90 \%$ credible interval included zero).

Together, the differences in intercepts and slopes relating degree days to age- 0 walleye length resulted in diverging walleye lengths in invaded versus uninvaded lake-years over the course of the growing season (Fig. 3a). As degree days accumulated within a year, the magnitude of the differences between age- 0 walleye length in invaded lakes compared to uninvaded lakes increased, with the largest differences in Mille Lacs, where Bythotrephes and zebra mussels cooccurred (Fig. 3b). Walleye in the presence of Bythotrephes were highly likely (posterior probability approaching 1) to be smaller than walleye from uninvaded lake-years across a wide range of degree day values (Fig. 3c). Uncertainty in the response of walleye growth was highest for zebra mussels (Fig. 3c). At low degree day values, walleye from zebra mussel invaded systems were unlikely to be smaller than walleye from uninvaded systems, but by the end of the summer the posterior probability of walleye in invaded lakes being smaller than those in uninvaded lakes approached 1.0 (Fig. 3c).

By mid-August, age- 0 walleye in lakes containing zebra mussels were on average $18 \mathrm{~mm}(14 \%)$ smaller than walleye in uninvaded lakes (Fig. 4). Walleye in lakes containing Bythotrephes were $15 \mathrm{~mm}$ (12\%) smaller, and walleye in lakes containing both AIS were on average $32 \mathrm{~mm}(25 \%)$ smaller than walleye in uninvaded lakes. Uncertainty in these estimates and high variability in growth rates resulted in wide ranges of predicted end of season walleye lengths. Despite this variability, the $90 \%$ credible interval of estimated differences for each category of invaded lakes did not contain zero. Still, walleye length varied substantially among lakes and years, with mid-August lengths varying by more than $50 \mathrm{~mm}$ even within uninvaded lakes (Figure S2). Within invaded lakes, walleye were 

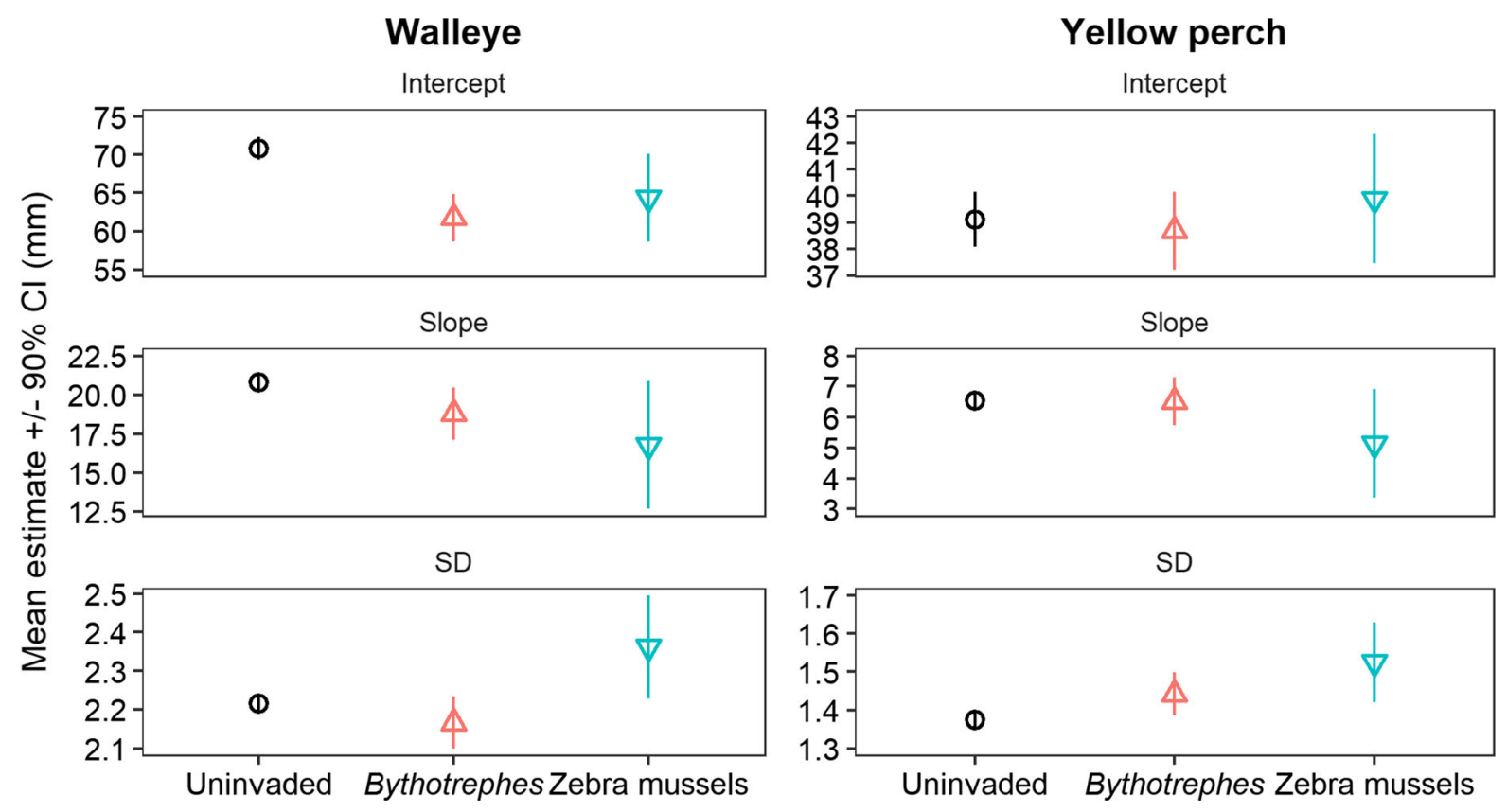

Fig. 2 Estimated intercept, slope, and standard deviations (SD) of the relationship between degree days and fish length for walleye (left) and yellow perch (right) as a function of invasion status. Points are mean estimates; lines are $90 \%$ credible intervals (CI)

Table 2 Estimated (mean and $90 \%$ credible interval) of intercepts $\left(\gamma_{n}^{\alpha}\right)$, slopes $\left(\gamma_{n}^{\beta}\right)$, and standard deviations (SDs; $\gamma_{n}^{\sigma}$ ) from the model relating age- 0 fish length to standardized degree days

Also shown are estimated differences (mean and $90 \%$ credible interval) from uninvaded systems as a function of invasion status ${ }^{\mathrm{a}}$ Credible interval does not include zero

\begin{tabular}{|c|c|c|c|}
\hline Invasion category & Coefficient & Mean $(90 \% \mathrm{CI})$ & Difference from uninvaded $(90 \% \mathrm{CI})$ \\
\hline \multicolumn{4}{|l|}{ Walleye } \\
\hline Uninvaded & Intercept & $70.82(69.35,72.28)$ & - \\
\hline Bythotrephes & Intercept & $61.75(58.65,64.85)$ & $-9.07(-12.22,-5.95)^{\mathrm{a}}$ \\
\hline Zebra mussels & Intercept & $64.34(58.61,70.09)$ & $-6.48(-12.22,-0.73)^{\mathrm{a}}$ \\
\hline Uninvaded & Slope & $20.78(20.15,21.43)$ & - \\
\hline Bythotrephes & Slope & $18.78(17.11,20.44)$ & $-2.00(-3.78,-0.23)^{\mathrm{a}}$ \\
\hline Zebra mussels & Slope & $16.76(12.66,20.87)$ & $-4.02(-8.15,0.10)$ \\
\hline Uninvaded & $\mathrm{SD}$ & $2.22(2.19,2.24)$ & - \\
\hline Bythotrephes & $\mathrm{SD}$ & $2.17(2.10,2.23)$ & $-0.05(-0.12,0.02)$ \\
\hline Zebra mussels & SD & $2.36(2.23,2.50)$ & $0.15(0.01,0.28)^{\mathrm{a}}$ \\
\hline \multicolumn{4}{|l|}{ Yellow perch } \\
\hline Uninvaded & Intercept & $39.10(38.06,40.14)$ & - \\
\hline Bythotrephes & Intercept & $38.69(37.22,40.15)$ & $-0.41(-1.58,0.77)$ \\
\hline Zebra mussels & Intercept & $39.88(37.47,42.32)$ & $0.77(-1.49,3.07)$ \\
\hline Uninvaded & Slope & $6.54(6.25,6.83)$ & - \\
\hline Bythotrephes & Slope & $6.52(5.74,7.30)$ & $-0.02(-0.85,0.80)$ \\
\hline Zebra mussels & Slope & $5.13(3.37,6.90)$ & $-1.41(-3.18,0.38)$ \\
\hline Uninvaded & $\mathrm{SD}$ & $1.37(1.35,1.39)$ & - \\
\hline Bythotrephes & SD & $1.44(1.39,1.50)$ & $0.07(0.01,0.13)^{\mathrm{a}}$ \\
\hline Zebra mussels & $\mathrm{SD}$ & $1.52(1.42,1.63)$ & $0.15(0.05,0.26)^{\mathrm{a}}$ \\
\hline
\end{tabular}



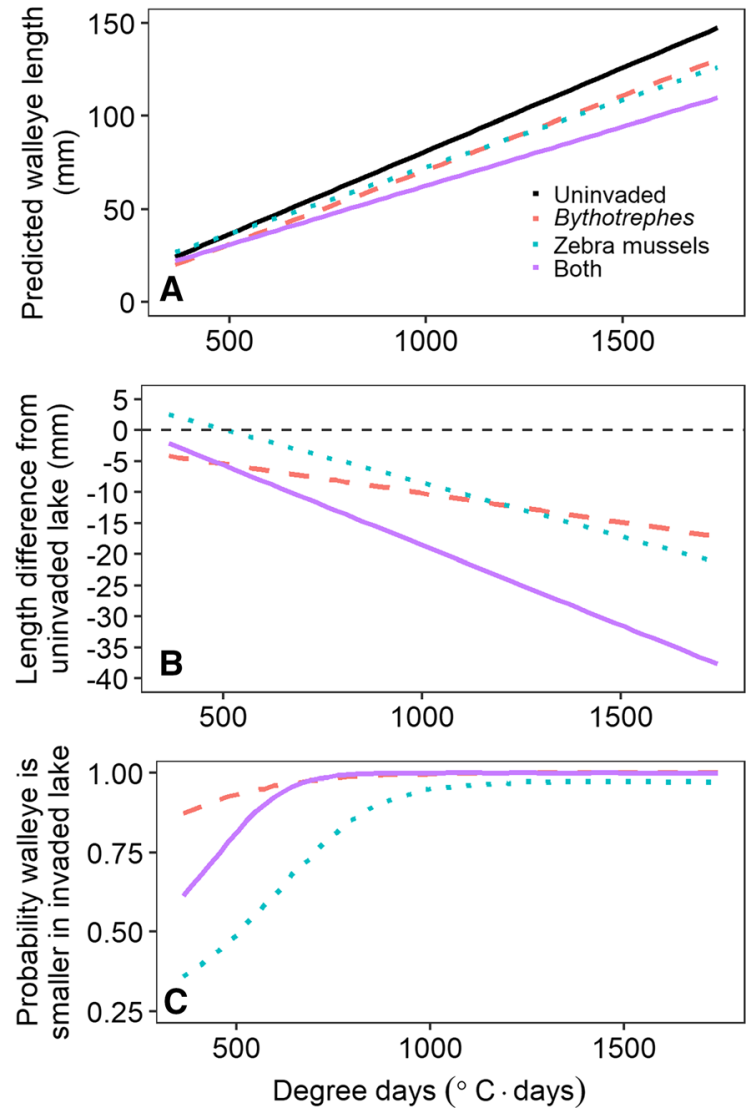

Fig. 3 Differences in age-0 walleye length metrics depend on degree days. a Predicted walleye length as a function of invasion status, b difference in length compared to uninvaded systems; and c posterior probabilities that walleye were smaller in invaded lake-years compared to uninvaded lake-years across a range of degree day values (base $5{ }^{\circ} \mathrm{C}$ ). Colors represent invasion status

smaller when zebra mussels were present compared to uninvaded years in every case, while the lake- and year-specific effects of Bythotrephes were much more variable (Figure S3). Lake-specific model fits are shown in Figure $\mathrm{S} 4$.

\section{Yellow perch}

Contrary to our expectation, age- 0 yellow perch were not consistently smaller in lakes with zebra mussels or Bythotrephes, although lengths were more variable in invaded systems. The presence of zebra mussels was not associated with differences in yellow perch length at mid-summer (Fig. 2; intercept), the estimated intercept was $0.77 \mathrm{~mm}(1.9 \%)$ greater and the $90 \%$ credible interval included zero (Table 2). On average, age-0 yellow perch grew $1.4 \mathrm{~mm}$ (22\%) more slowly per degree day increase when zebra mussels were present (Fig. 2; slope), although the 90\% credible interval of this difference included zero (Table 2). Yellow perch exhibited $11 \%$ higher variability in growth per degree day when zebra mussels were present (Fig. 2; Table 2; SD).

The presence of Bythotrephes did not affect yellow perch length at mid-summer (Fig. 2; intercept,). The intercept of the relationship between degree days and yellow perch length was $0.41 \mathrm{~mm}(1 \%)$ smaller, and the $90 \%$ credible interval included zero (Table 2). Yellow perch growth per degree day increase was also unaffected by the presence of Bythotrephes (mean difference in slope was $-0.02 \mathrm{~mm} /$ standardized degree day or $0.2 \%$ slower growth and the $90 \%$ credible interval included zero; Table 2). Yellow perch growth per degree day was $5 \%$ more variable in the presence of Bythotrephes (Fig. 2; Table 2; SD).

Yellow perch lengths in lakes invaded by zebra mussels diverged slightly from those in uninvaded lakes and lakes invaded by Bythotrephes over the course of the growing season (Fig. 5a). As degree days accumulated, the magnitude of the differences between age- 0 yellow perch total length in zebra mussel infested lakes compared to uninvaded lakes increased, although differences were generally small (Fig. 5b). The posterior probability of yellow perch being smaller in lakes with zebra mussels or both zebra mussels and Bythotrephes increased as degree days accumulated, but never exceeded 0.8 (Fig. 5c).

No differences in age- 0 yellow perch lengths were detectable in mid-August (Fig. 6). Yellow perch in the presence of Bythotrephes were $1.5 \mathrm{~mm}(3 \%)$ larger than those in uninvaded lakes. Yellow perch in the presence of zebra mussels or both AIS were on average 3 and $4 \mathrm{~mm}(6 \%)$ smaller, respectively, than yellow perch in uninvaded systems. In all cases, the $90 \%$ credible interval of estimated differences for each category of invaded lakes included zero. As was the case with walleye, yellow perch total length varied substantially among lakes and years, with end of season length varying by up to $40 \mathrm{~mm}$ even within uninvaded lakes (Figure S5). Within invaded lakes, yellow perch were smaller in years invaded by zebra mussels in one of the three invaded lakes, while yearspecific effects of Bythotrephes were highly variable 

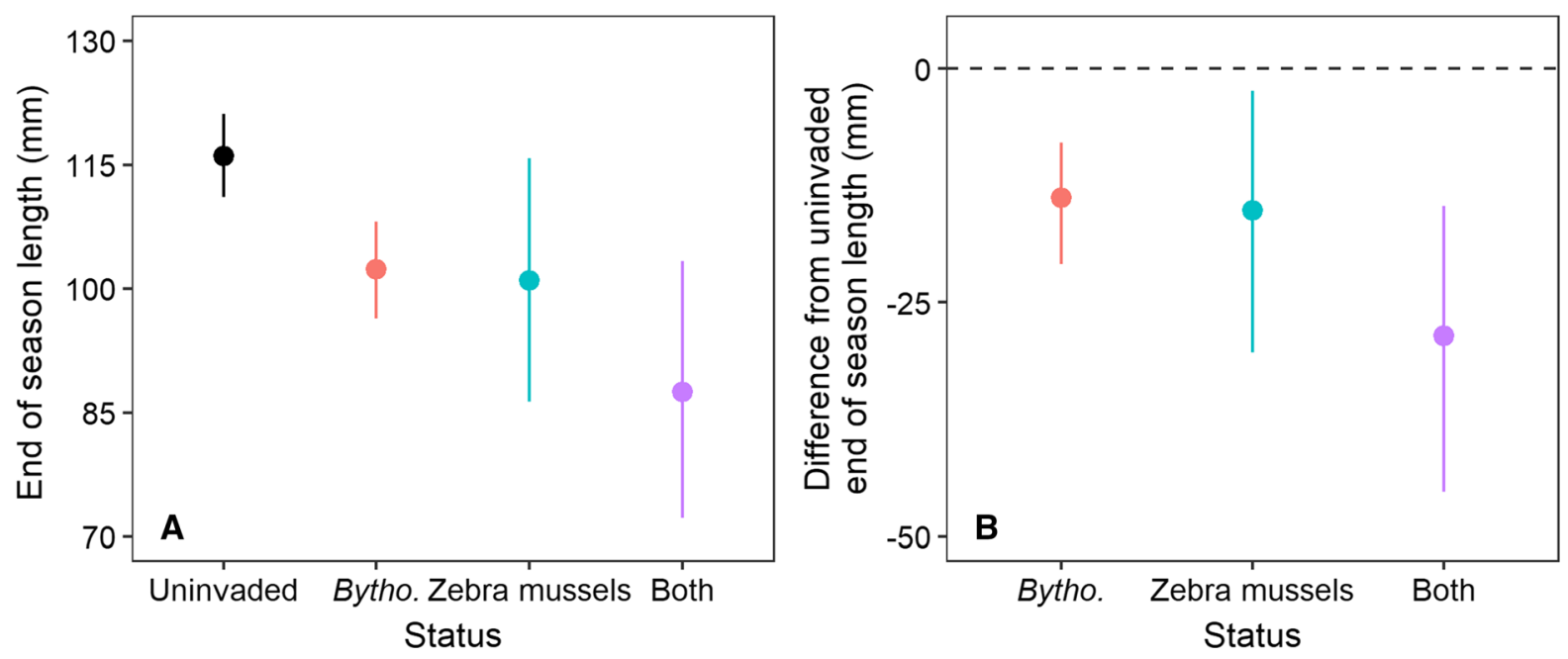

Fig. 4 a Predicted age- 0 walleye length and $\mathbf{b}$ difference in predicted walleye length at 1400 degree days as a function of invasion status. Points represent mean estimates, bars represent $90 \%$ credible intervals

(Figure S6). Lake specific model fits are shown in Figure S7.

\section{Discussion}

Documented impacts of invasive zebra mussels and Bythotrephes on fish are variable across locations and time periods. Here, we use a 35-year dataset from 9 lakes to demonstrate that early life growth of an important top predator, walleye, is influenced by these aquatic invasive species. The magnitude of the estimated effects of each AIS on first year walleye growth were remarkably similar. Walleye were smaller at mid-summer and grew more slowly throughout the growing season in the presence of each species, resulting in mid-August lengths that were 15 and $18 \mathrm{~mm}$ (12 and 14\%) smaller in lakes containing Bythotrephes and zebra mussels, respectively, compared to uninvaded systems. Growth responses varied among lakes, years, and individuals, and suggest some degree of decoupling of growth from temperature in systems invaded by zebra mussels.

The mechanisms through which zebra mussels and Bythotrephes affect walleye early life growth likely differ. Walleye rely on zooplankton prey for a portion of their first year of life (Wu and Culver 1992; Mittelbach and Persson 1998; Galarowicz et al. 2006), so AIS-induced changes in zooplankton prey resources are likely to impact walleye at this life stage. Bythotrephes reduce zooplankton biomass (Boudreau and Yan 2003; Barbiero and Tuchman 2004; Kerfoot et al. 2016), change community composition (Strecker et al. 2006; Bunnell et al. 2012), and alter behavior (Pangle and Peacor 2006; Pangle et al. 2007) including vertical migration patterns (Bourdeau et al. 2015). Zebra mussels also influence zooplankton biomass, size structure, and community composition (Macisaac 1996; Pace et al. 1998; Idrisi et al. 2001; Higgins and Vander Zanden 2010) indirectly by reducing phytoplankton biomass and community composition as well as directly by consuming microzooplankton (e.g., Kissman 2010). In both cases, lack of access to preferred zooplankton prey on which walleye rely in their early life could explain our finding that walleye were smaller at mid-summer in the presence of either AIS. However, we also observed continued negative effects throughout the growing season when Bythotrephes were present, even after walleye were capable of shifting to other prey resources. Walleye grew 19\% more slowly per degree day increase when zebra mussels were present, although variability in this response means that results were not statistically distinguishable from zero. These changes could indicate that littoral resources do not compensate for reduced energy flow to the pelagic food web in lakes invaded by either species. Bythotrephes may sequester energy if planktivorous prey fishes are unable to consume them (Barnhisel and 

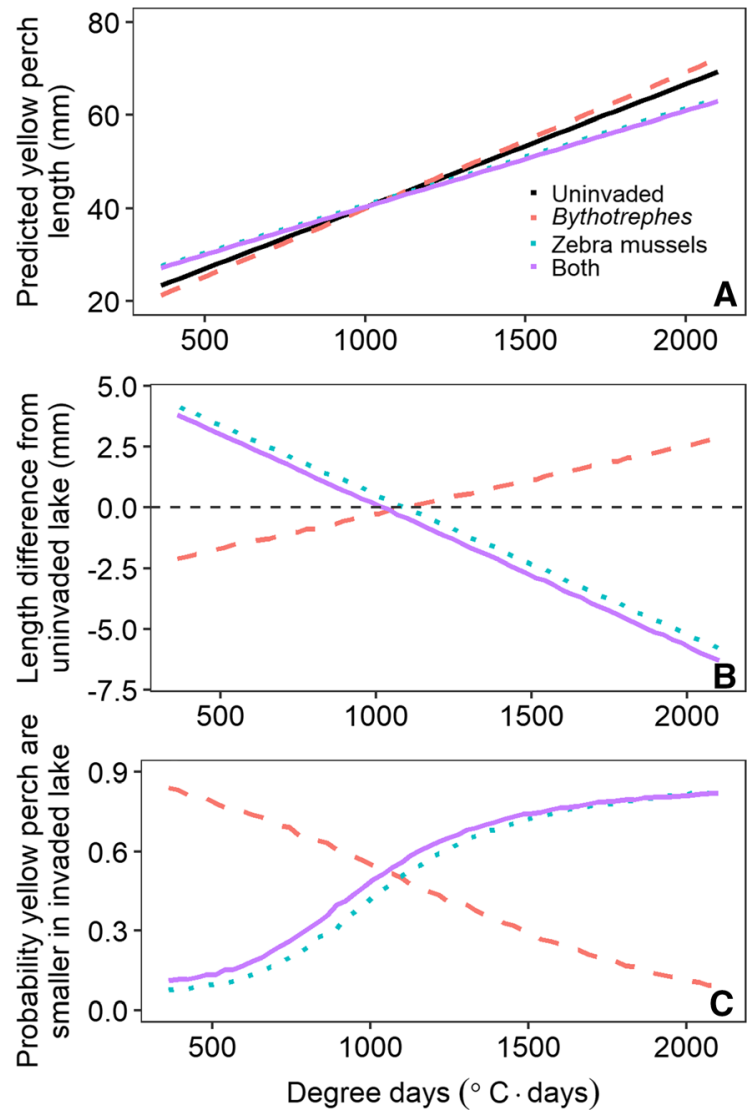

Fig. 5 Differences in age-0 yellow perch length metrics depend on degree days. a Predicted yellow perch length as a function of invasion status, b difference in length compared to uninvaded systems; and c posterior probabilities that yellow perch were smaller in inavaded lake-years compared to uninvaded lakeyears across a range of degree day values (base $5^{\circ} \mathrm{C}$ ). Colors represent invasion status

Kerfoot 2004; Compton and Kerfoot 2004) and because their production cannot compensate for the loss of production from native zooplankton declines (Kerfoot et al. 2016). Zebra mussels reduce pelagic production and increase benthic invertebrate biomass and production (Gergs et al. 2009; Burlakova et al. 2012; Karatayev et al. 2015). Fish that are able to access these increased benthic prey resources are expected to be more resilient to zebra mussel invasion (Higgins and Vander Zanden 2010), although fish growth response depends on the abundance and energy density of available prey pre- and post-invasion (McNickle et al. 2006; Lumb et al. 2007; Nalepa et al. 2009; Herbst et al. 2013). The observed variability in the response of walleye growth to zebra mussels suggests differences in the capacity of fish to access this increased benthic production. Additionally, increased water clarity associated with zebra mussels can reduce walleye production (Geisler et al. 2016), and walleye in lakes with high water clarity rely more heavily on pelagic energy sources due to their preference for low light conditions (Tunney et al. 2018), potentially explaining lower growth of age-0 walleye associated with zebra mussels.

Interestingly, although both walleye and yellow perch rely on zooplankton prey for portions of their first year of life, estimated effects of either AIS on yellow perch growth were not distinguishable from zero. The lack of response of yellow perch growth was unexpected, given the documented negative effects of Bythotrephes on yellow perch growth in a subset of our study lakes and years chosen to minimize the confounding influences of a rainbow smelt invasion and a change in lake level management (Staples et al. 2017). Yellow perch are more of a foraging generalist compared to walleye (Graeb et al. 2005; Weber et al. 2010); thus, it is possible that yellow perch are able to shift to alternative prey items more easily when favored prey items become limited. For example, selective predation by Bythotrephes results in a shift in zooplankton community composition towards prey items that are more difficult to capture and ingest (Kerfoot et al. 2016). Yellow perch might be buffered from the negative effects of these changes because they can consume these less preferred prey items sooner and more easily than walleye. Yellow perch growth also did not respond negatively to zebra mussel invasion, similar to other studies (Mayer et al. 2000; Idrisi et al. 2001), again suggesting that yellow perch are capable of accessing alternative resources as food webs shift in the presence of AIS (Mitchell et al. 1996).

Changes in the density of age- 0 fish can also cause changes in growth via density dependent processes (e.g., Rose et al. 2001, Irwin et al. 2009). The abundance of age- 0 yellow perch in Lake Erie increased following zebra mussel invasion (Trometer and Busch 1999), and yellow perch densities were also high in Rainy and Kabetogama lakes in the invaded years for which growth was reduced as reported in Staples et al. (2017). The presence of dreissenid mussels has been associated with yellow perch recruitment failures in Lake Michigan (Marsden and Robillard 2004), which would be expected to result in 

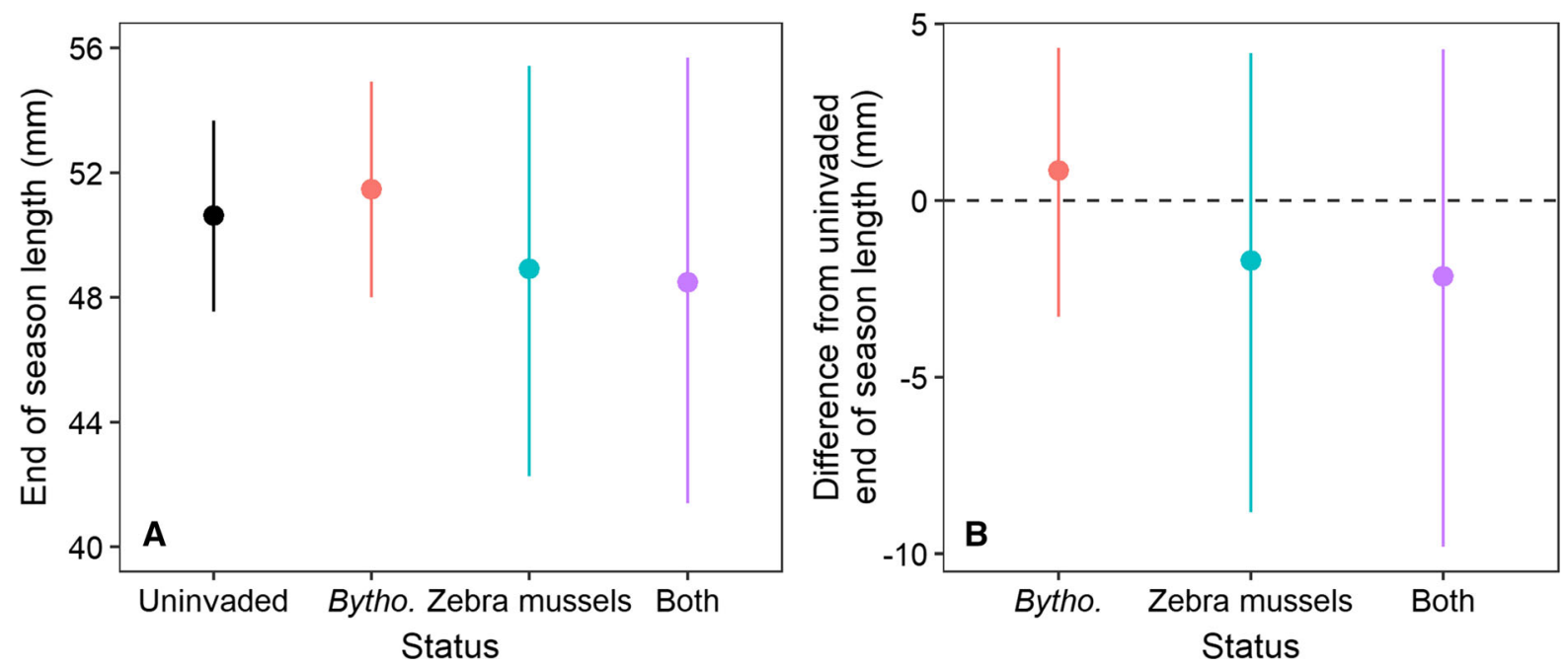

Fig. 6 a Predicted age-0 yellow perch length and $\mathbf{b}$ Difference in predicted yellow perch length at 1400 degree days as a function of invasion status. Points represent mean estimates, bars represent $90 \%$ credible intervals

increased growth if density dependence was an important driver of growth (Headley and Lauer 2008). Furthermore, walleye and yellow perch interact, and first year abundance and growth rates of each are intimately connected (e.g., Maloney and Johnson 1957; Rudstam et al. 1996; Rutherford et al. 1999; Pierce et al. 2006; Dembkowski et al. 2017). Abundant walleye populations can limit yellow perch recruitment, resulting in fast growth of age-0 yellow perch and slow growth of age-0 walleye. Conversely, low density walleye populations allow for abundant yellow perch, slow yellow perch growth, and fast walleye growth. We did not examine changes in age- 0 fish abundance associated with invasion due to lack of data on age-0 fish densities. Future research examining effects of AIS on early life growth and abundance of fishes across a broader gradient of lakes may help elucidate mechanisms and understand differences among species and lakes.

Reduced growth rates resulting in smaller end of season length for age- 0 walleye may have important implications for walleye fisheries. Slow growth during early life of fishes is associated with higher mortality due to increased predation (Houde 1987, 2008; Rose et al. 1999), lower energy reserves leading to lower winter survival (Post and Prankevicius 1987; Johnson and Evans 1991; Post et al. 1998), and later access to energetically profitable prey items (Wu and Culver 1992). These impacts on early life survival can impact eventual recruitment to later life stages and to the fishery (Anderson 1988; Sogard 1997). Walleye size at the end of their first growing season is a good predictor of recruitment to later life stages in Lake Oneida (Forney 1974, 1976, 1977), Lake Mendota (Madenjian and Carpenter 1991), and in some South Dakota lakes (Grote et al. 2018), but not in Lake Erie (Madenjian et al. 1996). These differences could be due to differences in the relative importance of cannibalism in each system, which in turn is a function of the abundance of age- 0 walleye relative to other prey sources, and winter duration (Forney 1976; Madenjian et al. 1996). Furthermore, age-0 piscivores can be an important prey item for larger fish (Chevalier 1973; Forney 1974; Ahrenstorff unpublished data), and the 12 and $14 \%$ reductions in walleye length associated with Bythotrephes and zebra mussels, respectively, translate to reductions in weight of 31 and $35 \%$ if weight is approximated as a cube function of length (Froese 2006).

Understanding how ecosystem-level effects of strongly interacting invasive species are transmitted through food webs to influence fish populations is challenging. Invasion ecology as a discipline has been criticized for a lack of generalizability and quantitative assessments of comparable invaded and uninvaded systems (Parker et al. 1999; Hulme et al. 2013). Among-system differences in impacts could be a result of spurious results reflecting a statistical or sampling artifact (Hulme et al. 2013) or can reflect real heterogeneity in impacts due to complex interacting 
drivers of change and indirect effects (White et al. 2006; Brown et al. 2011; Strecker et al. 2011). We combined data across lakes and years to quantify effects of zebra mussels and Bythotrephes on walleye and yellow perch early life growth using statistical models that explicitly account for variability and uncertainty and are generalizable across lakes. At the same time, our statistical approach can estimate lakeand year-specific effects that may be useful for developing lake-specific management plans. Our results suggest that zebra mussels and Bythotrephes can influence walleye through indirect pathways, although the mechanisms of such effects are unknown. Of course, these lakes are subject to other stressors including climate change, nutrient pollution, and harvest (Ormerod et al. 2010; Carpenter et al. 2011), all of which have the potential to influence fish populations via numerous pathways. We detected biologically significant effects of AIS on early life growth of a top predator fish in spite of the existence of these potentially confounding factors. Continued long-term monitoring of fish populations and lake ecosystems will be critical for testing whether similar effects are observed in other time periods and other lakes, and for understanding the mechanisms through which invasive species and other stressors influence fish and aquatic food webs.

Acknowledgements We are extremely grateful to the countless Minnesota DNR staff who collected and compiled the data for this analysis. Special thanks to Gerry Albert, Matt Hennen, Eric Jensen, Tony Kennedy, Brett Nelson, Carl Pedersen, Doug Schultz, Phil Talmage, and Ben Vondra for their support and assistance with this project. We are grateful to project team members Valerie Brady, Will French, and Holly Kelly for their valuable contributions to this project. Thanks also to Charles Anderson and two anonymous reviewers for comments that improved the quality of this manuscript. Funding was provided by the Minnesota Environmental and Natural Resources Trust Fund as recommended by the Minnesota Aquatic Invasive Species Research Center (MAISRC) and the Legislative-Citizen Commission on Minnesota Resources (LCCMR). Use of trade names is for identification purposes only and does not imply endorsement by the U.S. government.

Open Access This article is licensed under a Creative Commons Attribution 4.0 International License, which permits use, sharing, adaptation, distribution and reproduction in any medium or format, as long as you give appropriate credit to the original author(s) and the source, provide a link to the Creative Commons licence, and indicate if changes were made. The images or other third party material in this article are included in the article's Creative Commons licence, unless indicated otherwise in a credit line to the material. If material is not included in the article's Creative Commons licence and your intended use is not permitted by statutory regulation or exceeds the permitted use, you will need to obtain permission directly from the copyright holder. To view a copy of this licence, visit http://creativecommons.org/licenses/by/4.0/.

\section{References}

Anderson JT (1988) A review of size dependent survival during pre-recruit stages of fishes in relation to recruitment. J Northwest Atl Fish Sci 8:55-66

Barbiero RP, Tuchman ML (2004) Changes in the crustacean communities of Lakes Michigan, Huron, and Erie following the invasion of the predatory cladoceran Bythotrephes longimanus. Can J Fish Aquat Sci 61:2111-2125

Barnhisel DR, Kerfoot WC (2004) Fitting into food webs: behavioral and functional response of young lake trout (Salvelinus namaycush) to an introduced prey, the spiny cladoceran (Bythotrephes cederstroemi). J Great Lakes Res 30:300-314

Boudreau SA, Yan ND (2003) The differing crustacean zooplankton communities of Canadian Shield lakes with and without the nonindigenous zooplanktivore Bythotrephes longimanus. Can J Fish Aquat Sci 60:1307-1313

Bourdeau PE, Pangle KL, Peacor SD (2015) Factors affecting the vertical distribution of the zooplankton assemblage in Lake Michigan: the role of the invasive predator Bythotrephes longimanus. J Great Lakes Res 41:115-124

Bremigan MT, Dettmers JM, Mahan AL (2003) Zooplankton selectivity by larval yellow perch in Green Bay, Lake Michigan. J Great Lakes Res 29:501-510

Brooks SP, Gelman A (1997) General methods for monitoring convergence of iterative simulations. J Comput Graph Stat 7:434-455

Brown GP, Phillips BL, Shine R (2011) The ecological impact of invasive cane toads on tropical snakes: Field data do not support laboratory-based predictions. Ecology 92:422-431

Bunnell DB, Keeler KM, Puchala EA, Davis BM, Pothoven SA (2012) Comparing seasonal dynamics of the Lake Huron zooplankton community between 1983-1984 and 2007 and revisiting the impact of Bythotrephes planktivory. J Great Lakes Res 38:451-462

Burlakova LE, Karatayev AY, Karatayev VA (2012) Invasive mussels induce community changes by increasing habitat complexity. Hydrobiologia 685:121-134

Carpenter SR, Stanley EH, Vander Zanden MJ (2011) State of the world's freshwater ecosystems: physical, chemical, and biological changes. Annu Rev Environ Resour 36:75-99

Chevalier JR (1973) Cannibalism as a factor in first year survival of walleye in Oneida Lake. Trans Am Fish Soc 102:739-744

Chezik KA, Lester NP, Venturelli PA (2013) Fish growth and degree-days I: selecting a base temperature for a single population study. Can J Fish Aquat Sci 71:47-55

Compton JA, Kerfoot CW (2004) Colonizing Inland Lakes: consequences of YOY fish ingesting the spiny cladoceran (Bythotrephes cederstroemi). J Great Lakes Res 30(Supplement 1):315-326 
Dembkowski DJ, Weber MJ, Wuellner MR (2017) Factors influencing recruitment and growth of age-0 yellow perch in eastern South Dakota glacial lakes. Fish Manag Ecol 24:372-381

Fernandez RJ, Rennie MD, Sprules WG (2009) Changes in nearshore zooplankton associated with species invasions and potential effects on larval lake whitefish (Coregonus clupeaformis). Int Rev Hydrobiol 94:226-243

Forney JL (1974) Interactions between yellow perch abundance, walleye predation, and survival of alternate prey in Oneida Lake, New York. Trans Am Fish Soc 103:15-24

Forney JL (1976) Year-class formation in the walleye (Stizostedion vitreum vitreum) population of Oneida Lake, New York, 1966-73. J Fish Res Board Can 33:783-792

Forney JL (1977) Evidence of inter- and intra-specific competition as factors regulating walleye (Stizostedion vitreum vitreum) biomass in Oneida Lake, New York. J Fish Res Board Can 34:1812-1820

Froese R (2006) Cube law, condition factor and weight-length relationships: history, meta-analysis and recommendations. J Appl Ichthyol 22:241-253

Galarowicz TL, Adams JA, Wahl DH (2006) The influence of prey availability on ontogenetic diet shifts of a juvenile piscivore. Can J Fish Aquat Sci 63:1722-1733

Geisler ME, Rennie MD, Gillis DM, Higgins SN (2016) A predictive model for water clarity following dreissenid invasion. Biol Invasions 18:1989-2006

Gelman A, Hill J (2007) Data analysis using regression and multilevel/hierarchical models. Cambridge University Press, New York

Gergs R, Rinke K, Rothhaupt K-O (2009) Zebra mussels mediate benthic-pelagic coupling by biodeposition and changing detrital stoichiometry. Freshw Biol 54:1379-1391

Gopalan G, Culver DA, Wu L, Trauben BK (1998) Effects of recent ecosystem changes on the recruitment of young-ofthe-year fish in western Lake Erie. Can J Fish Aquat Sci 55:2572-2579

Graeb BDS, Galarowicz T, Wahl DH, Dettmers JM, Simpson MJ (2005) Foraging behavior, morphology, and life history variation determine the ontogeny of piscivory in two closely related predators. Can J Fish Aquat Sci 62:2010-2020

Grote JD, Wuellner MR, Blackwell BG, Lucchesi DO (2018) Evaluation of potential overwinter mortality of age- 0 walleye and appropriate age- 1 sampling gear. J Fish Wildl Manag 9:65-74

Guiliano A (2011) Effects of zebra mussel invasion on juvenile steelhead distribution, diet, growth, and condition in the Muskegon River, Michigan. University of Michigan, Ann Arbor

Headley HC, Lauer TE (2008) Density-dependent growth of yellow perch in southern Lake Michigan, 1984-2004. N Am J Fish Manag 28:57-69

Hecky RE, Smith RE, Barton DR, Guildford SJ, Taylor WD, Charlton MN, Howell T (2004) The nearshore phosphorus shunt: a consequence of ecosystem engineering by dreissenids in the Laurentian Great Lakes. Can J Fish Aquat Sci 61:1285-1293

Herbst SJ, Marsden JE, Lantry BF (2013) Lake Whitefish diet, condition, and energy density in Lake Champlain and the lower four Great Lakes following dreissenid invasions. Trans Am Fish Soc 142:388-398

Higgins SN, Vander Zanden MJ (2010) What a difference a species makes: a meta-analysis of dreissenid mussel impacts on freshwater ecosystems. Ecol Monogr 80:179-196

Hoffman JC, Smith ME, Lehman JT (2001) Perch or plankton: top-down control of Daphnia by yellow perch (Perca flavescens) or Bythotrephes cederstroemi in an inland lake? Freshw Biol 46:759-775

Honsey AE, Venturelli PA, Lester NP (2019) Bioenergetic and limnological foundations for using degree-days derived from air temperatures to describe fish growth. Can J Fish Aquat Sci 76:657-669

Houde ED (1987) Fish early life dynamics and recruitment variability. In: American Fisheries Society Symposium, vol 2

Houde ED (2008) Emerging from Hjort's shadow. J Northwest Atl Fish Sci 41:53-70

Hulme PE, Pyšek P, Jarošík V, Pergl J, Schaffner U, Vilà M (2013) Bias and error in understanding plant invasion impacts. Trends Ecol Evol 28:212-218

Idrisi N, Mills EL, Rudstam LG, Stewart DJ (2001) Impact of zebra mussels (Dreissena polymorpha) on the pelagic lower trophic levels of Oneida Lake, New York. Can J Fish Aquat Sci 58:1430-1441

Irwin BJ, Treska TJ, Rudstam LG, Sullivan PJ, Jackson JR, VanDeValk AJ, Forney JL (2008) Estimating walleye (Sander vitreus) density, gear catchability, and mortality using three fishery-independent data sets for Oneida Lake, New York. Can J Fish Aquat Sci 65:1366-1378

Irwin BJ, Rudstam LG, Jackson JR, VanDeValk AJ, Forney JL, Fitzgerald DG (2009) Depensatory mortality, density-dependent growth, and delayed compensation: disentangling the interplay of mortality, growth, and density during early life stages of yellow perch. Trans Am Fish Soc 138:99-110

Jacobson PC (2004) Contribution of stocked walleyes (Sander vitreus) to the statewide harvest in Minnesota. In: Barry TP, Malison JA (eds) Proceedings of PERCIS III: the third international percid fish symposium. The University of Wisconsin Sea Grant Institute, Madison

Johnson TB, Evans DO (1991) Behaviour, energetics, and associated mortality of young-of-the-year white perch (Morone americana) and yellow perch (Perca flavescens) under simulated winter conditions. Can J Fish Aquat Sci 48:672-680

Kaemingk MA, Galarowicz TL, Clevenger JA, Clapp DF, Lenon HL (2012) Fish assemblage shifts and population dynamics of smallmouth bass in the Beaver Archipelago, northern Lake Michigan: a comparison between historical and recent time periods amidst ecosystem changes. Trans Am Fish Soc 141:550-559

Karatayev AY, Burlakova LE, Padilla DK (2002) Impacts of zebra mussels on aquatic communities and their role as ecosystem engineers. In: Leppäkoski E, Gollasch S, Olenin $\mathrm{S}$ (eds) Invasive aquatic species of Europe Distribution, impacts and management. Springer, Dordrecht, pp 433-446

Karatayev AY, Burlakova LE, Padilla DK (2015) Zebra versus quagga mussels: a review of their spread, population 
dynamics, and ecosystem impacts. Hydrobiologia 746:97-112

Kellner K (2018) jagsUI: a wrapper around 'rjags' to streamline 'JAGS' analyses. R package version 1.5.0

Kerfoot WC, Hobmeier MM, Yousef F, Lafrancois BM, Maki RP, Hirsch JK (2016) A plague of waterfleas (Bythotrephes): impacts on microcrustacean community structure, seasonal biomass, and secondary production in a large inland-lake complex. Biol Invasions 18:1121-1145

Kissman CE (2010) Dreissenid mussels (Dreissena polymorpha and Dreissena bugensis) reduce microzooplankton and macrozooplankton biomass in thermally stratified lakes. Limnol Oceanogr 55:1851-1859

Korovchinsky NM, Arnott SE (2019) Taxonomic resolution of the North American invasive species of the genus Bythotrephes Leydig, 1860 (Crustacea: Cladocera: Cercopagididae). Zootaxa 4691:125-138

Lumb CE, Johnson TB, Andrew Cook H, Hoyle JA (2007) Comparison of lake whitefish (Coregonus clupeaformis) growth, condition, and energy density between Lakes Erie and Ontario. J Great Lakes Res 33:314-325

Macisaac HJ (1996) Potential abiotic and biotic impacts of zebra mussels on the inland waters of North America. Am Zool 36:287-299

Madenjian CP, Carpenter SR (1991) Individual-based model for growth of young-of-the-year walleye: a piece of the recruitment puzzle. Ecol Appl 1:268-279

Madenjian CP, Tyson JT, Knight RL, Kershner MW, Hansen MJ (1996) First-year growth, recruitment, and maturity of walleyes in western Lake Erie. Trans Am Fish Soc 125:821-830

Maloney JE, Johnson FH (1957) Life histories and inter-relationships of walleye and yellow perch, especially during their first summer, in two Minnesota lakes. Trans Am Fish Soc 85:191-202

Marsden JE, Robillard SR (2004) Decline of yellow perch in southwestern Lake Michigan, 1987-1997. N Am J Fish Manag 24:952-966

Mavrin AS, Strel'nikova AP (2011) Feeding, development, and growth of juvenile perch perca fluviatilis in mesocosms in the presence of filter-feeding zebra mussel Dreissena polymorpha pallas. Inland Water Biol 4:232-241

Mayer CM, VanDeValk AJ, Forney JL, Rudstam LG, Mills EL (2000) Response of yellow perch (Perca flavescens) in Oneida Lake, New York, to the establishment of zebra mussels (Dreissena polymorpha). Can J Fish Aquat Sci 57:742-754

McNickle GG, Rennie MD, Sprules WG (2006) Changes in benthic invertebrate communities of South Bay, Lake Huron following invasion by zebra mussels (Dreissena polymorpha), and potential effects on lake whitefish (Coregonus clupeaformis) diet and growth. J Great Lakes Res 32:180-193

Minnesota Department of Natural Resources (MNDNR) (1997) Potential, target, and current yields for Minnesota's 10 large walleye lakes. Special Publication 151. Minnesota Department of Natural Resources, Section of Fisheries, St. Paul

Mitchell MJ, Mills EL, Idrisi N, Michener R (1996) Stable isotopes of nitrogen and carbon in an aquatic food web recently invaded by (Dreissena polymorpha) (Pallas). Can J Fish Aquat Sci 53:1445-1450

Mittelbach GG, Persson L (1998) The ontogeny of piscivory and its ecological consequences. Can J Fish Aquat Sci 55:1454-1465

Nalepa TF, Pothoven SA, Fanslow DL (2009) Recent changes in benthic macroinvertebrate populations in Lake Huron and impact on the diet of lake whitefish (Coregonus clupeaformis). Aquat Ecosyst Health Manag 12:2-10

Neuheimer AB, Taggart CT (2007) The growing degree-day and fish size-at-age: the overlooked metric. Can J Fish Aquat Sci 64:375-385

Nielsen LA (1980) Effect of Walleye (Stizostedion vitreum vitreum) predation on juvenile mortality and recruitment of yellow perch (Perca flavescens) in Oneida Lake, New York. Can J Fish Aquat Sci 37:11-19

Nienhuis S, Haxton T, Dunkley T (2014) An empirical analysis of the consequences of zebra mussel invasions on fisheries in inland, freshwater lakes in Southern Ontario. Manag Biol Invasions 5:287-302

Ormerod SJ, Dobson M, Hildrew AG, Townsend CR (2010) Multiple stressors in freshwater ecosystems. Freshw Biol 55:1-4

Pace ML, Findlay SEG, Fischer D (1998) Effects of an invasive bivalve on the zooplankton community of the Hudson River. Freshw Biol 39:103-116

Pangle KL, Peacor SD (2006) Non-lethal effect of the invasive predator Bythotrephes longimanus on Daphnia mendotae. Freshw Biol 51:1070-1078

Pangle KL, Peacor SD, Johannsson OE (2007) Large nonlethal effects of an invasive invertebrate predator on zooplankton population growth rate. Ecology 88:402-412

Parker IM, Simberloff D, Lonsdale WM, Goodell K, Wonham M, Kareiva PM, Williamson MH, Von Holle B, Moyle PB, Byers JE et al (1999) Impact: toward a framework for understanding the ecological effects of invaders. Biol Invasions 1:3-19

Pierce RB, Tomcko CM, Negus MT (2006) Interactions between stocked walleyes and native yellow perch in Lake Thirteen, Minnesota: a case history of percid community dynamics. N Am J Fish Manag 26:97-107

Plummer M (2003) JAGS: a program for analysis of Bayesian graphical models using Gibbs sampling. In: Hornik K, Leish F, Zeileis A (eds) Proceedings of the 3rd international workshop on distributed statistical computing. Technische Universit at Wien, Wien, p 125

Post JR, Prankevicius AB (1987) Size-selective mortality in young-of-the-year yellow perch (Perca flavescens): evidence from otolith microstructure. Can J Fish Aquat Sci 44:1840-1847

Post DM, Kitchell JF, Hodgson JR (1998) Interactions among adult demography, spawning date, growth rate, predation, overwinter mortality, and the recruitment of largemouth bass in a northern lake. Can J Fish Aquat Sci 55:2588

R Core Team (2018) R: a language and environment for statistical computing. R Foundation for Statistical Computing, Vienna

Read JS, Walker JI, Appling AP, Blodgett DL, Read EK, Winslow LA (2015) geoknife: reproducible web-processing of large gridded datasets. Ecography 39:349-408 
Rennie MD, Strecker AL, Palmer ME (2011) Bythotrephes invasion elevates trophic position of zooplankton and fish: implications for contaminant biomagnification. Biol Invasions 13:2621

Rose KA, Rutherford ES, McDermot DS, Forney JL, Mills EL (1999) Individual-based model of yellow perch and walleye populations in Oneida Lake. Ecol Monogr 69:127-154

Rose KA, Cowan JH, Winemiller KO, Myers RA, Hilborn R (2001) Compensatory density dependence in fish populations: importance, controversy, understanding and prognosis. Fish Fish 2:293-327

Roswell CR (2011) Growth, condition, and diets of age-0 Saginaw Bay yellow perch: implications for recruitment. M.S. Purdue University, United States-Indiana

Rudstam LG, Green DM, Forney JL, Stang DL, Evans JT (1996) Evidence of interactions between walleye and yellow perch in New York State lakes. Ann Zool Fenn 33:443-449

Rutherford ES, Rose KA, Mills EL, Forney JL, Mayer CM, Rudstam LG (1999) Individual-based model simulations of a zebra mussel (Dreissena polymorpha) induced energy shunt on walleye (Stizostedion vitreum) and yellow perch (Perca flavescens) populations in Oneida Lake, New York. Can J Fish Aquat Sci 56:2148-2160

Sogard SM (1997) Size-selective mortaility in the juvenile stage of teleost fishes: a review. Bull Mar Sci 60:1129-1157

Staples DF, Maki RP, Hirsch JK, Kerfoot WC, LeDuc JF, Burri T, Lafrancois BM, Glase J (2017) Decrease in young-ofthe-year yellow perch growth rates following Bythotrephes longimanus invasion. Biol Invasions 19:1-9

Strayer DL, Caraco NF, Cole JJ, Findlay S, Pace ML (1999) Transformation of freshwater ecosystems by bivalves: a case study of zebra mussels in the Hudson River. Bioscience 49:19-27

Strayer DL, Hattala KA, Kahnle AW (2004) Effects of an invasive bivalve (Dreissena polymorpha) on fish in the Hudson River estuary. Can J Fish Aquat Sci 61:924-941

Strecker AL, Arnott SE, Yan ND, Girard R (2006) Variation in the response of crustacean zooplankton species richness and composition to the invasive predator Bythotrephes longimanus. Can J Fish Aquat Sci 63:2126-2136

Strecker AL, Beisner BE, Arnott SE, Paterson AM, Winter JG, Johannsson OE, Yan ND (2011) Direct and indirect effects of an invasive planktonic predator on pelagic food webs. Limnol Oceanogr 56:179-192
Trometer ES, Busch WDN (1999) Changes in age-0 fish growth and abundance following the introduction of zebra mussels Dreissena polymorpha in the western basin of Lake Erie. N Am J Fish Manag 19:604-609

Truemper HA, Lauer TE, McComish TS, Edgell RA (2006) Response of yellow perch diet to a changing forage base in southern Lake Michigan, 1984-2002. J Great Lakes Res 32:806-816

Tunney TD, McCann KS, Jarvis L, Lester NP, Shuter BJ (2018) Blinded by the light? Nearshore energy pathway coupling and relative predator biomass increase with reduced water transparency across lakes. Oecologia 186:1031-1041

U .S. Department of the Interior, U. S. Fish and Wildlife Service, U. S. Department of Commerce, and U. S. Census Bureau (2011) National survey of fishing, hunting, and wildlifeassociated recreation. Minnesota, p 94

Vanderploeg HA, Liebig JR, Carmichael WW, Agy MA, Johengen TH, Fahnenstiel GL, Nalepa TF (2001) Zebra mussel (Dreissena polymorpha) selective filtration promoted toxic Microcystis blooms in Saginaw Bay (Lake Huron) and Lake Erie. Can J Fish Aquat Sci 58:1208-1221

Walsh JR, Carpenter SR, Zanden MJV (2016) Invasive species triggers a massive loss of ecosystem services through a trophic cascade. Proc Natl Acad Sci 113:4081-4085

Weber MJ, Dettmers JM, Wahl DH, Czesny SJ (2010) Effects of predator-prey interactions and benthic habitat complexity on selectivity of a foraging generalist. Trans Am Fish Soc 139:1004-1013

White EM, Wilson JC, Clarke AR (2006) Biotic indirect effects: a neglected concept in invasion biology. Divers Distrib 12:443-455

Wingate P, Schupp DH (1984) Large lake sampling guide. Minnesota DNR Special Publication, vol 140

Wu L, Culver DA (1992) Ontogenetic diet shift in Lake Erie age-0 yellow perch (Perca flavescens): a size-related response to zooplankton density. Can J Fish Aquat Sci 49:1932-1937

Yan N, Pawson T (1997) Changes in the crustacean zooplankton community of Harp Lake, Canada, following invasion by Bythotrephes cederstromi. Freshw Biol 37:409-425

Publisher's Note Springer Nature remains neutral with regard to jurisdictional claims in published maps and institutional affiliations. 